\title{
Sodic-ferripedrizite, a new monoclinic amphibole bridging the magnesium-iron-manganese-lithium and the sodium-calcium groups
}

\section{Roberta Oberti, ${ }^{1}$ José M. Caballero, ${ }^{2, *}$ Luisa OtTOlini, ${ }^{1}$ Sol LóPeZ-ANDrés, ${ }^{3}$ AND VICTOR HERREROS ${ }^{2}$}

\author{
${ }^{1}$ CNR-Centro di Studio per la Cristallochimica e la Cristallografia (CSCC), via Ferrata 1, I-27100 Pavia, Italy \\ ${ }^{2}$ Departamento de Petrología y Geoquímica, Universidad Complutense de Madrid, Ciudad Universitaria, 28040-Madrid, Spain \\ ${ }^{3}$ Departamento de Cristalografía y Mineralogía, Universidad Complutense de Madrid, Ciudad Universitaria, 28040-Madrid, Spain
}

\begin{abstract}
Sodic-ferripedrizite, ideally $\mathrm{Na}(\mathrm{LiNa})\left(\mathrm{Fe}_{2}^{3} \mathrm{Mg}_{2} \mathrm{Li}\right) \mathrm{Si}_{8} \mathrm{O}_{22}(\mathrm{OH})_{2}$, is the second new amphibole endmember found in episyenites formed after cordierite-bearing porphyritic granites in the East Pedriza Massif (Central System, Spain). It is green, vitreous, translucent, non-fluorescent and brittle, and has gray streak, $\mathrm{H}(\mathrm{Mohs})=6$, splintery fracture, perfect $\{110\}$ cleavage, $D_{\text {meas }}=3.15, D_{\text {calc }}=3.15 \mathrm{~g} /$ $\mathrm{cm}^{3}$. In plane-polarized light, sodic-ferripedrizite is strongly pleochroic, $X=$ green blue, $Y=$ blue green, $Z=$ yellow green $(X>Y>Z) ; Y=b, X^{\wedge} c=4^{\circ}, Z^{\wedge} c=-8^{\circ}$. It is biaxial positive: $\alpha=1.694$ (1), $\beta=1.698(1)$, and $\gamma=1.702(1) ; 2 V_{Z}=83(2)^{\circ}$ and $2 V_{Z \text {,calc }}=85(3)^{\circ}$, dispersion $r>v$. Sodic-ferripedrizite is monoclinic, space group $C 2 / m, a=9.536(1), b=17.789(2), c=5.277(1) \AA, \beta=102.53^{\circ}, V=$ $873.8(1) \AA^{3}$. The five strongest lines in the X-ray powder-diffraction pattern $[d$ in $\AA[I](h k l)$ are $3.397[3](131), 3.056[10](310), 2.749[5](330), 2.699[6](151)$, and 1.639[4](461). Analysis by electron microprobe and flame photometry gave an average chemical formula of ${ }^{\mathrm{A}}\left(\mathrm{Na}_{0.70} \mathrm{~K}_{0.03}\right){ }^{\mathrm{B}}\left(\mathrm{Li}_{1.34} \mathrm{Na}\right.$ $\left.{ }_{0.58} \mathrm{Ca}_{0.08}\right)\left(\mathrm{Mg}_{1.75} \mathrm{Fe}_{1.65}^{3+} \mathrm{Li}_{0.88} \mathrm{Fe}_{0.32}^{2+} \mathrm{Al}_{0.21} \mathrm{Ti}_{0.11} \mathrm{Mn}_{0.07}^{2+} \mathrm{Zn}_{0.01}\right) \mathrm{Si}_{8.00} \mathrm{O}_{22}\left(\mathrm{OH}_{1.35} \mathrm{~F}_{0.65}\right)$. Structure refinement of one crystal of pedrizite and of another crystal with higher clinoholmquistite component, both of which were also analyzed by ion microprobe for light and volatile elements, allowed us to assess $\mathrm{Li}$ partitioning among the $\mathrm{B}$ - and $\mathrm{C}$-group sites and the active crystal-chemical mechanisms; Li is ordered at the [6+2]-coordinated position in the M4 cavity and at the M3 site. Thus, sodic-ferripedrizite encompasses the different site-preferences and crystal-chemical mechanisms observed for Li in amphiboles of the $\mathrm{Mg}-\mathrm{Fe}-\mathrm{Mn}-\mathrm{Li}$ group (clinoholmquistite series) and the Na-Ca group (leakeite series). These data and other recent results on synthetic amphiboles suggest that miscibility between the two groups of B-cations is far more extensive than previously expected.
\end{abstract}

\section{INTRODUCTION}

Lithium may be incorporated in the amphibole structure in two different ways. It can enter the B-sites [in the clinoholmquistite series, ideally $\mathrm{Li}_{2}\left(\mathrm{Mg}, \mathrm{Fe}^{2+}\right)_{3}\left(\mathrm{Al}, \mathrm{Fe}^{3+}\right)_{2} \mathrm{Si}_{8} \mathrm{O}_{22}$ $(\mathrm{OH}, \mathrm{F})_{2}$ ] or the C-sites [in the leakeite series, ideally $\mathrm{Na} \mathrm{Na}_{2}$ $\left.\left(\mathrm{Mg}, \mathrm{Fe}^{2+}\right)_{2}\left(\mathrm{Al}, \mathrm{Fe}^{3+}\right)_{2} \mathrm{Li} \mathrm{Si}_{8} \mathrm{O}_{22}(\mathrm{OH}, \mathrm{F})_{2}\right]$. Detection and quantification of $\mathrm{Li}$ in amphiboles is difficult, but became easier with the advent of the ion microprobe, which allows in-situ analysis of single crystals. Recent work on CLi-bearing amphiboles (Hawthorne et al. 1992, 1993, 1994, 1996a, 1996b, 1998) allowed the definition of constraints and crystal-chemical mechanisms of ${ }^{\mathrm{C}} \mathrm{Li}$ incorporation. Sodian fluorian clinoholmquistite was the only ${ }^{\mathrm{B}} \mathrm{Li}$ clinoamphibole for which a (poor quality) structure refinement has been available for a long time (Litvin et al. 1975). Sodic ferri-clinoferroholmquistite, ideally $\mathrm{Li}_{2}$ $\left(\mathrm{Fe}^{2+} \mathrm{Mg}\right)_{3} \mathrm{Fe}_{2}^{3+} \mathrm{Si}_{8} \mathrm{O}_{22}(\mathrm{OH})_{2}$, was found in the Sierra de Guadarrama (Spain) and its complete chemical and structural description was given by Caballero et al. (1998).
We have discovered recently amphibole compositions further enriched in both $\mathrm{Na}$ and $\mathrm{Li}$, such that their charge arrangement is that of leakeite, but the B-site composition is ideally (LiNa). Therefore, a new root name has been proposed: pedrizite from Pedriza, the protected natural reserve near Madrid that is the type locality. This amphibole has been recognized as a new mineral by the IMA Commission on New Minerals and Mineral Names, and given the name sodic-ferripedrizite (98-061). Holotype material has been deposited in the Museo Nacional de Ciencias Naturales, Madrid (Spain), code number MNCN-18342.

\section{OCCURRENCE AND PETROGENESIS}

The amphiboles described here occur in the hydrothermal episyenites of the Eastern Pedriza Massif (Sierra de Guadarrama, Central System, Spain). The episyenites consist of discrete, irregularly spaced, tabular bodies that replace cordierite-bearing monzogranites over an area of $1.5 \times 0.8 \mathrm{~km}$ (Cathelineau 1986; Caballero et al. 1991). The episyenite bodies have an N-100-E orientation and preserve the porphyritic texture of the original granite (Villaseca and Pérez-Soba 1989). The mineral assemblage consists of an albite matrix containing pyroxenes, Li-amphiboles, and micas as intergranular aggregates. 
Sodic-ferripedrizite was collected in the Arroyo de la Yedra Valley [Spanish Military Map number 509 (19-20), scale $1: 50000,4^{\text {th }}$ edition (1986)], about 20 m east of the occurrence of sodic ferri-clinoferroholmquistite (Caballero et al. 1998). The episyenite consists of albite, augite-aegirine (Ae 28-43), titanite, magnetite, apatite, and 3\% (by volume) of sodicferripedrizite. Late hydrothermal processes with decreasing temperature formed tainiolite + microcline (after biotite and albite, respectively), quartz + ferro-actinolite (after feldspar and sodic-ferripedrizite) and sericite + kaolinite + oxides (after albite and mafic minerals).

The episyenites of the Sierra de Guadarrama are not related to the late-Hercynian granitic magmatism that ended about 285 Ma ago with the emplacement of rare and small granitic plutons (González-Casado et al. 1996). Instead, these rocks are associated with an extensional tectonic re-activation of the Hercynian basement at $\cong 277 \mathrm{Ma}$. Geochemical data suggest that the Liamphibole-bearing episyenites formed by interaction of former granitoids with hydrothermal fluids of meteoric origin and low salinity close to $520{ }^{\circ} \mathrm{C}$. Fluid inclusions in pyroxene and epidote from calcic episyenites of the Sierra de Guadarrama gave fluid pressures in the range $150-170 \mathrm{MPa}$; this clearly represents an upper limit for fluid pressure, because quartz dissolution and its replacement by albite is expected to occur under lower fluid pressures (Caballero 1993, 1999). The coexistence locally of different amphiboles (sodic ferri-clinoferroholmquistite and sodic-ferripedrizite) in the same episyenite body suggests that the percolating fluid was not homogeneous; sodic-ferripedrizite probably formed from fluids with higher $\mathrm{Na}$ activity (i.e., high $a_{\mathrm{Na}}{ }^{+} / a_{\mathrm{Ca}^{2+}}$, in agreement with the complete granitic feldspar albitization and absence of garnet.

\section{PHYSICAL AND OPTICAL PROPERTIES}

Sodic-ferripedrizite occurs as granular aggregates of subhedral crystals of mean size $0.18(11) \times 0.10(6) \mathrm{mm}^{2}$ and as euhedral micro-inclusions in albite, quartz, and titanite [0.06(4) $\left.\times 0.01(1) \mathrm{mm}^{2}\right]$. Crystals are prismatic, elongated on [001] up to $1 \mathrm{~mm}$, bounded by $\{110\}$ cleavage faces, and the prism direction is usually terminated by irregular fractures. The $\{010\}$ and $\{001\}$ pinacoids may be observed, whereas $\{100\}$ pinacoids are rare and always poorly developed.

Sodic-ferripedrizite is green and semitranslucent with a vitreous luster; it has a gray streak and shows no fluorescence under long- or short wave ultraviolet light. It has a splintery fracture and Mohs hardness of $\sim 6$. Cleavage is perfect on $\{110\}$, intersecting at $\sim 55^{\circ}$, and parting on (001) is poor. The measured and calculated densities are $3.15 \mathrm{~g} / \mathrm{cm}^{3}$ and $3.15 \mathrm{~g} / \mathrm{cm}^{3}$, respectively.

Optic axial angles and refractive indices were measured with a spindle stage; the orientation was measured with an universal stage. In transmitted light, sodic-ferripedrizite is strongly pleochroic with $X=$ green blue, $Y=$ blue green, and $Z=$ yellow green, and absorption $X>Y>Z ; Y=b, X^{\wedge} c=4(1)^{\circ}$ and $Z^{\wedge} a$ $\approx-8^{\circ}$. It is biaxial positive with indices of refraction $\alpha=$ 1.694(1), $\beta=1.698(1)$, and $\gamma=1.702(2) ; 2 V_{Z}=83(2)^{\circ}$ and $2 V_{Z \text {, calc }}=85(3)^{\circ}$, under monochromatic yellow light $(\lambda=589$ $\mathrm{nm})$. Dispersion is medium, $r>v\left(2 V_{Z}=79(3)^{\circ}\right.$ at $\left.500 \mathrm{~nm}\right)$. Calculation of the Gladstone-Dale relationship yields a com- patibility index $\left(1-\mathrm{K}_{\mathrm{P}} / \mathrm{K}_{\mathrm{C}}\right)$ of 0.006 , which is considered to be superior agreement (Mandarino 1981).

\section{MINERAL COMPOSITION}

Wavelength-dispersive analyses on grain-mount thin sections were obtained with a JEOL-8900M electron-microprobe at the Universidad Complutense of Madrid. Standard operating conditions were excitation voltage of $15 \mathrm{kV}$, specimen current of $20 \mathrm{nA}$, peak-count time of $10 \mathrm{~s}$ and background-count time of $5 \mathrm{~s}$. The following standards and crystals were used for $K \alpha$ X-ray lines: Si; albite, PET; Ti and Ca: kaersutite, PET; Al: sillimanite, TAP; Fe and Mn: almandine, LIF; Mg: kaersutite, TAP; Zn: gahnite, LIF; Na: albite, TAP; K: microcline, PET; F: apatite, TAP. Data reduction was done with the CITZAF software package (Armstrong 1989). A mineral concentrate was also analyzed for Li by flame photometry and for $\mathrm{FeO}$ by redox titration. The purity of the concentrate was estimated to be 98.3(3)\% from modal analysis; the major impurity was ferroactinolite, which intimately replaces sodic-ferripedrizite.

The formula unit (Table 1) was calculated assuming that the tetrahedral sites are occupied by $\mathrm{Si}$, as suggested from crystal structure refinement. The calculated $\mathrm{FeO}$ wt $\%$ of $2.79 \pm$ $1.22 \%$ is in close agreement with that resulting from redox titration $(2.5 \pm 0.55 \mathrm{wt} \%)$, supporting the above assumptions. The estimated standard deviations give a measure of the intergranular variability in the sample, which is always wider than the observed intragranular variability due to chemical zoning.

The crystals used for crystal-structure refinement were subsequently mounted, polished, and analyzed by ion-microprobe techniques to quantify in-situ light and volatile elements $(\mathrm{Li}$, $\mathrm{H}, \mathrm{F}$, and $\mathrm{Cl}$ ). Ion-microprobe analysis was done at $\mathrm{CSCC}$ on a Cameca IMS 4f probe with an $\mathrm{O}^{-}$primary beam $\leq 10 \mu \mathrm{m} \varnothing(\varnothing$ $=$ focus diameter), corresponding to a beam current of $\sim 4 \mathrm{nA}$. Secondary positive-ion currents were measured at masses $1(\mathrm{H})$, 7 (Li), 19 (F), and 30 (Si, used as the reference element), and corrected for isotopic abundance. $\mathrm{B}, \mathrm{Be}$, and $\mathrm{Cl}$ ion signals,

TABLE 1. Average chemical analysis and formula unit* $(n=24,17$ analysis of grains) for sodic-ferripedrizite from the Pedriza Massif

\begin{tabular}{|c|c|c|c|c|c|}
\hline$\overline{\mathrm{SiO}_{2}}$ & 57.70 & (28) & $\mathrm{Si}$ & 8.000 & \\
\hline $\mathrm{TiO}_{2}$ & 1.04 & (11) & $\mathrm{Ti}$ & 0.108 & (12) \\
\hline $\mathrm{Al}_{2} \mathrm{O}_{3}$ & 1.26 & (22) & $\mathrm{Al}$ & 0.206 & (37) \\
\hline $\mathrm{Fe}_{2} \mathrm{O}_{3}{ }^{*}$ & 15.81 & (1.66) & $\mathrm{Fe}^{3+}$ & 1.650 & (171) \\
\hline $\mathrm{FeO}^{*}$ & 2.79 & (1.22) & $\mathrm{Fe}^{2+}$ & 0.324 & (142) \\
\hline $\mathrm{MnO}$ & 0.58 & (5) & $\mathrm{Mn}^{2+}$ & 0.068 & (6) \\
\hline $\mathrm{MgO}$ & 8.45 & (76) & $\mathrm{Mg}$ & 1.747 & (150) \\
\hline $\mathrm{ZnO}$ & 0.12 & (6) & $\mathrm{Zn}$ & 0.012 & (6) \\
\hline $\mathrm{CaO}$ & 0.56 & (28) & $\mathrm{Li}$ & 0.885 & (67) \\
\hline $\mathrm{Li}_{2} \mathrm{O}$ & 3.98 & (2) & Total C & 5.000 & \\
\hline $\mathrm{Na}_{2} \mathrm{O}$ & 4.78 & (33) & $\mathrm{Ca}$ & 0.083 & (42) \\
\hline $\mathrm{K}_{2} \mathrm{O}$ & 0.15 & (14) & $\mathrm{Na}$ & 0.582 & (80) \\
\hline $\mathrm{H}_{2} \mathrm{O}^{*}$ & 1.46 & (4) & $\mathrm{Li}$ & 1.335 & (73) \\
\hline $\mathrm{F}$ & 1.48 & (9) & Total B & 2.000 & \\
\hline $\mathrm{F} \equiv \mathrm{O}$ & -0.62 & & $\mathrm{Na}$ & 0.703 & (115) \\
\hline \multirow[t]{5}{*}{ Sum } & 99.54 & $w t \%$ & $\mathrm{~K}$ & 0.027 & (25) \\
\hline & & & Total A & 0.730 & \\
\hline & & & 0 & 22.000 & \\
\hline & & & $\mathrm{OH}$ & 1.351 & (39) \\
\hline & & & $\mathrm{F}$ & 0.649 & (39) \\
\hline
\end{tabular}

${ }^{*}$ Calculated assuming $\mathrm{OH}+\mathrm{F}=2$ apfu and $\mathrm{T}$ sites fully occupied by $\mathrm{Si}$. 
tested at 11, 9, and 37 mass numbers (amu), were negligible. The energy-filtering technique was used to reduce matrix effects affecting light-element ionization. The two crystals were left in the ion-microprobe sample-chamber to degas overnight, together with low-H standard amphiboles that were successively used in the calibration procedure. Several medium-silica standards belonging to the $\mathrm{H}$-calibration curve for silicates (Ottolini et al. 1995) were analyzed in the same analytical session to test reproducibility of the experimental procedures. For $\mathrm{Li}$, the Ceran glass, which is representative of the CSCC calibration curve for $\mathrm{Li}$ in silicates, was used as the primary standard (Ottolini et al. 1993). For F, the calibration curve obtained for silicates was used (Ottolini et al. 1994), and the matrix effects due to the high Fe content (Ottolini, unpublished results) were also taken into account. The accuracy of the SIMS analysis for $\mathrm{H}_{2} \mathrm{O}$ and $\mathrm{F}$ is estimated (pessimistically) to be around $15 \%$, whereas that for $\mathrm{Li}$ is around $10 \%$. Crystal $\mathrm{P}(1)$ is sodicferripedrizite with ${ }^{\mathrm{M} 4} \mathrm{Na}>0.5 \mathrm{apfu}$, whereas crystal $\mathrm{P}(2)$ has the same charge arrangement but a slightly lower ${ }^{\mathrm{M} 4} \mathrm{Na}$ content.

Unit formulae were calculated on the basis of $24(\mathrm{O}, \mathrm{OH}, \mathrm{F}$, and $\mathrm{Cl}$ ), and the $\mathrm{Fe}^{2+} / \mathrm{Fe}^{3+}$ ratio was varied to obtain $8.0 \mathrm{Si}$ pfu, as suggested by structure refinement (Table 2). Comparison of the refined site-scatterings with those calculated from the unit formulae shows good agreement (Table 2), a measure of the accuracy of the two independent analyses; the small deviations are due to the difficulties in modeling very asymmetric electron-density maxima at the A and M4 sites.

TABLE 2. Ion-microprobe analyses $(\mathrm{H}, \mathrm{Li}$, and $\mathrm{F})$ and unit formulae for the two refined crystals

\begin{tabular}{lll}
\hline \hline & $\mathrm{P}(1)$ & $\mathrm{P}(2)$ \\
\hline $\mathrm{Li}_{2} \mathrm{O}$ & 3.88 & 4.33 \\
$\mathrm{H}_{2} \mathrm{O}$ & 1.24 & 1.15 \\
$\mathrm{~F}$ & 1.92 & 2.09
\end{tabular}

$\begin{array}{lll}\mathrm{Si} & 8.00 & 8.00 \\ \mathrm{Ti} & 0.11 & 0.11 \\ \mathrm{Al} & 0.21 & 0.21\end{array}$

$\mathrm{Al}$

$\mathrm{Fe}^{3+} \quad 1.63 \quad 1.39$

$\mathrm{Fe}^{2+} \quad 0.36 \quad 0.60$

$\begin{array}{lll}\mathrm{Zn} & 0.01 & 0.01\end{array}$

$\begin{array}{lll}\mathrm{Mn} & 0.07 & 0.07\end{array}$

$\begin{array}{lll}\mathrm{Mg} & 1.77 & 0.07\end{array}$

Li

Sum C

Li

$\mathrm{Na}$

$\mathrm{Ca}$

Sum B

$\mathrm{Na}$

K

Sum A

$\mathrm{OH}$

$\mathrm{F}$

Sum $\mathrm{O} 3$

$0.84 \quad 0.84$

$5.00 \quad 5.00$

$1.35 \quad 1.60$

$0.60 \quad 0.35$

$\begin{array}{ll}0.05 & 0.05 \\ 2.00 & 2.00\end{array}$

$\begin{array}{ll}2.00 & 2.00 \\ 0.70 & 0.95\end{array}$

$0.03 \quad 0.03$

$0.73 \quad 0.98$

$1.16 \quad 1.07$

$\begin{array}{ll}0.84 & 0.93 \\ 2.00 & 2.00\end{array}$

$\begin{array}{lrr}\text { B-group sites } & 82.9,82.7 & 81.7,82.7 \\ \text { A-group sites } & 11.0,11.6 & 9.2,9.6\end{array}$

$\begin{array}{lll}\text { A-group sites } & 9.4,8.3 & 9.9,11.0\end{array}$

Notes: Unit formulae were calculated based on $24(\mathrm{O}, \mathrm{OH}, \mathrm{F})$, and the $\mathrm{Fe}^{3+} / \mathrm{Fe}^{2+}$ ratio was varied to obtain $8.0 \mathrm{Si}$ apfu.

* The first number is the refined value; the second number is the calculated.

\section{X-RAY ANALYSIS AND STRUCTURE REFINEMENT}

The X-ray powder-diffraction pattern was recorded from a mineral separate with a Philips X-PERT diffractometer with graphite-monochromatized $\mathrm{Cu} K \alpha \mathrm{X}$-radiation; NBS Si was used as a standard. The positions of the peaks were determined with the Philips PC-APD software, and unit-cell parameters were refined starting from the corrected $d$ values with the program UNITCELL (Holland and Redfern 1997). The indexed powder-pattern and refined unit-cell parameters are given in Table 3.

Several crystals were mounted on a Philips PW-1100 four-circle diffractometer and examined with graphitemonochromatized $\mathrm{MoK} \alpha \mathrm{X}$-radiation; crystal quality was assessed via the profile and width of Bragg diffraction peaks.

TABLE 3. Indexed X-ray powder-diffraction pattern of sodicferripedrizite from Pedriza Massif

\begin{tabular}{|c|c|c|c|}
\hline$h k l$ & Iobs & $d_{\text {obs }}(\AA)$ & $d_{\text {calc }}(\AA)$ \\
\hline 020 & 1 & 8.891 & 8.895 \\
\hline 110 & 24 & 8.246 & 8.248 \\
\hline 130 & 7 & 5.001 & 5.001 \\
\hline 200 & 5 & 4.654 & 4.654 \\
\hline 021 & 10 & 4.459 & 4.458 \\
\hline 040 & 22 & 4.446 & 4.447 \\
\hline 220 & 2 & 4.123 & 4.124 \\
\hline 111 & 3 & 4.035 & 4.034 \\
\hline$\overline{2} 01$ & 2 & 3.898 & 3.900 \\
\hline 131 & 1 & 3.819 & 3.818 \\
\hline$\overline{2} 21$ & 9 & 3.571 & 3.572 \\
\hline 131 & 28 & 3.397 & 3.396 \\
\hline 240 & 13 & 3.216 & 3.215 \\
\hline 310 & 100 & 3.056 & 3.057 \\
\hline 221 & 5 & 2.954 & 2.954 \\
\hline$\overline{1} 51$ & 6 & 2.897 & 2.897 \\
\hline 330 & 54 & 2.749 & 2.749 \\
\hline 151 & 60 & 2.699 & 2.699 \\
\hline$\overline{3} 31$ & 11 & 2.645 & 2.646 \\
\hline$\underline{061}$ & 14 & 2.570 & 2.570 \\
\hline$\overline{2} 02$ & 18 & 2.494 & 2.495 \\
\hline 170 & 5 & 2.451 & 2.452 \\
\hline$\overline{3} 51$ & 13 & 2.274 & 2.274 \\
\hline$\overline{4} 21$ & 6 & 2.245 & 2.243 \\
\hline$\overline{3} 12$ & 5 & 2.216 & 2.217 \\
\hline 261 & 18 & 2.153 & 2.153 \\
\hline$\overline{3} 32$ & 6 & 2.091 & 2.091 \\
\hline 202 & 5 & 2.071 & 2.071 \\
\hline 081 & 2 & 2.041 & 2.042 \\
\hline 351 & 10 & 2.010 & 2.009 \\
\hline 421 & 20 & 1.920 & 1.920 \\
\hline 242 & 4 & 1.877 & 1.878 \\
\hline 510 & 12 & 1.851 & 1.852 \\
\hline 191 & 6 & 1.785 & 1.784 \\
\hline$\overline{5} 12$ & 9 & 1.686 & 1.686 \\
\hline$\overline{2} 82$ & 6 & 1.660 & 1.660 \\
\hline 461 & 44 & 1.639 & 1.639 \\
\hline 480 & 12 & 1.607 & 1.608 \\
\hline$\overline{1} 53$ & 7 & 1.576 & 1.576 \\
\hline 600 & 7 & 1.552 & 1.551 \\
\hline$\overline{2} 63$ & 5 & 1.499 & 1.499 \\
\hline 223 & 5 & 1.487 & 1.487 \\
\hline 0120 & 7 & 1.482 & 1.482 \\
\hline$\underline{6} 02$ & 5 & 1.478 & 1.478 \\
\hline$\overline{6} 61$ & 23 & 1.396 & 1.397 \\
\hline 512 & 10 & 1.370 & 1.370 \\
\hline 532 & 5 & 1.338 & 1.338 \\
\hline$\overline{7} 10$ & 6 & 1.326 & 1.326 \\
\hline 730 & 5 & 1.298 & 1.298 \\
\hline$\overline{2} 122$ & 10 & 1.274 & 1.274 \\
\hline 661 & 2 & 1.269 & 1.269 \\
\hline
\end{tabular}

Notes: Unit-cell parameters: $a=9.536(1), b=17.789(2), c=5.277(1) \AA$, $\beta=102.53(1)^{\circ}, V=873.8(1) \AA^{3}$ 
Unit-cell dimensions were calculated from least-squares refinement of the $d$ values obtained from 50 rows of the reciprocal lattice by measuring the centroid of gravity of each reflection and of the corresponding antireflection in the range $-30<\theta<$ $30^{\circ}$. For the two crystals of this work, intensity data were collected for the monoclinic-equivalent pairs $(h k l$ and $h \bar{k} l)$ in the range $2<\theta<30^{\circ}$. Intensities were corrected for absorption, Lorentz, and polarization effects, averaged and reduced to structure factors.

Structure-refinement procedures were as described in Oberti et al. (1992) and Hawthorne et al. (1995). Reflections with $I>$ $5 \sigma_{I}[\mathrm{P}(1)]$ and $>3 \sigma_{I}[\mathrm{P}(2)]$ were considered as observed during structure refinement. Scattering curves for fully ionized chemical species were used at sites where chemical substitutions occur; neutral vs. ionized scattering curves were used at the T and anion sites (except O3). Refinement information and final

TABLE 4. Unit-cell dimensions and crystal-structure refinement information

\begin{tabular}{lcc}
\hline \hline & $\mathrm{P}(1)$ & $\mathrm{P}(2)$ \\
\hline$a(\AA)$ & $9.536(6)$ & $9.534(4)$ \\
$b(\AA)$ & $17.797(7)$ & $17.785(6)$ \\
$c(\AA)$ & $5.278(4)$ & $5.278(2)$ \\
$\beta\left(\left(^{\circ}\right)\right.$ & $102.54(4)$ & $102.52(3)$ \\
$V\left(\AA^{3}\right)$ & 874.4 & 873.7 \\
no. all & 1334 & 1333 \\
no. obs & 934 & 902 \\
$R_{\text {all }}$ & $3.3 \%$ & $4.7 \%$ \\
$R_{\text {obs }}$ & $1.7 \%$ & $2.0 \%$ \\
SEQ* & 918 & 930 \\
\hline${ }^{*}$ Sequence number in the CSCC amphibole database.
\end{tabular}

$R$ values in the space group $C 2 / m$ are in Table 4, atom positions, refined site-scatterings, and atom displacement parameters are in Table 5, and selected interatomic distances and angles are in Table 6 . Table $7^{1}$ lists the observed and calculated structure factors.

\section{SITE POPULATIONS AND CATION ORDERING}

\section{B-group sites}

Two different sites are available in amphiboles for cations in the $\mathrm{B}$ cavity. The larger cations $\left(\mathrm{Na}^{+}\right.$and $\left.\mathrm{Ca}^{2+}\right)$ occur at the eightfold-coordinated M4 site at $0, \sim 0.28,1 / 2$, and the smaller cations $\left(\mathrm{Li}^{+}, \mathrm{Mg}^{2+}, \mathrm{Mn}^{2+}\right.$, and $\left.\mathrm{Fe}^{2+}\right)$ occur at the $[6+2]$-coordinated M4' site at $0, \sim 0.24,1 / 2$. The two positions are usually separated by $\sim 0.4 \AA$ ( $0.46-0.47 \AA$ for the crystals of this work), and can thus be independently refined (carefully) with normalresolution (up to $\theta=30^{\circ}$ ) MoK $\alpha \mathrm{X}$-ray data; however, only their aggregate site scattering can be considered as reliable. The two crystals studied have different ${ }^{\mathrm{B}} \mathrm{Li}$ and ${ }^{\mathrm{B}} \mathrm{Na}$ contents which result in differences in refined site-scattering values (Table 5) and M4' coordination (Table 6). Fourier maps show the electron density within the B cavity to be asymmetric, with

${ }^{1}$ For a copy of Table 7, Document AM-00-039, contact the Business Office of the Mineralogical Society of America (see inside cover of a recent issue for price information). Deposit items may also be available on the American Mineralogist web site at http://www.minsocam.org.

TABLE 5. Atom coordinates, refined site-scattering values (ss, epfu), and atomic-displacement parameters $\left(B_{\text {eq }}, \AA^{2} ; \beta_{\mathrm{ii}} \times 10^{4}\right)$

\begin{tabular}{|c|c|c|c|c|c|c|c|c|c|c|c|}
\hline Atom & ss & $x / a$ & $y / b$ & $z / c$ & $B_{\text {eq }}$ & $\beta_{11}$ & $\beta_{22}$ & $\beta_{33}$ & $\beta_{12}$ & $\beta_{13}$ & $\beta_{23}$ \\
\hline \multirow[t]{2}{*}{$\mathrm{O} 1$} & & $0.1114(1)$ & $0.0906(1)$ & $0.2083(3)$ & 0.57 & 14 & 5 & 55 & -1 & 5 & -1 \\
\hline & & $0.1116(2)$ & $0.0906(1)$ & $0.2081(3)$ & 0.54 & 14 & 5 & 45 & 0 & 2 & 0 \\
\hline \multirow[t]{2}{*}{$\mathrm{O} 2$} & & $0.1209(1)$ & $0.1725(1)$ & $0.7311(2)$ & 0.68 & 16 & 6 & 64 & 1 & 6 & -1 \\
\hline & & $0.1210(2)$ & $0.1726(1)$ & $0.7311(3)$ & 0.63 & 13 & 6 & 61 & 0 & 7 & -1 \\
\hline \multirow[t]{2}{*}{$\mathrm{O} 3$} & 17.0 & $0.1150(2)$ & 0 & $0.6973(4)$ & 0.97 & 28 & 7 & 93 & 0 & 3 & 0 \\
\hline & 17.2 & $0.1158(2)$ & 0 & $0.6966(5)$ & 1.08 & 33 & 7 & 110 & 0 & 6 & 0 \\
\hline \multirow[t]{2}{*}{$\mathrm{O} 4$} & & $0.3726(1)$ & $0.2508(1)$ & $0.7862(3)$ & 0.90 & 32 & 5 & 80 & -5 & 3 & 2 \\
\hline & & $0.3727(2)$ & $0.2507(1)$ & $0.7856(3)$ & 0.86 & 33 & 5 & 67 & -5 & 3 & 0 \\
\hline \multirow[t]{2}{*}{ O5 } & & $0.3542(1)$ & $0.1292(1)$ & $0.0684(3)$ & 0.77 & 18 & 9 & 54 & 0 & 5 & 10 \\
\hline & & $0.3544(2)$ & $0.1292(1)$ & $0.0679(3)$ & 0.74 & 18 & 8 & 54 & 0 & 5 & 9 \\
\hline \multirow[t]{2}{*}{ O6 } & & $0.3471(1)$ & $0.1198(1)$ & $0.5683(3)$ & 0.86 & 20 & 9 & 63 & 1 & 7 & -9 \\
\hline & & $0.3469(2)$ & $0.1198(1)$ & $0.5680(3)$ & 0.84 & 20 & 9 & 62 & 2 & 10 & -9 \\
\hline \multirow[t]{2}{*}{ O7 } & & $0.3404(2)$ & 0 & $0.2826(4)$ & 0.85 & 21 & 4 & 128 & - & 10 & - \\
\hline & & $0.3407(3)$ & 0 & $0.2833(5)$ & 0.86 & 20 & 3 & 140 & - & 3 & - \\
\hline \multirow[t]{2}{*}{ T1 } & & $0.2835(1)$ & $0.0863(1)$ & $0.2811(1)$ & 0.42 & 14 & 3 & 38 & 0 & 3 & 0 \\
\hline & & $0.2835(1)$ & $0.0864(1)$ & $0.2811(1)$ & 0.42 & 14 & 3 & 36 & 0 & 2 & 0 \\
\hline \multirow[t]{2}{*}{ T2 } & & $0.2952(1)$ & $0.1714(1)$ & $0.7897(1)$ & 0.46 & 15 & 3 & 39 & -1 & 3 & 0 \\
\hline & & $0.2953(1)$ & $0.1715(1)$ & $0.7894(1)$ & 0.44 & 14 & 3 & 38 & -1 & 2 & -1 \\
\hline \multirow[t]{2}{*}{ M1 } & 27.3 & 0 & $0.0859(1)$ & - & 0.60 & 21 & 5 & 49 & - & 12 & - \\
\hline & 26.8 & 0 & $0.0857(1)$ & - & 0.56 & 18 & 5 & 43 & - & 13 & - \\
\hline \multirow[t]{2}{*}{ M2 } & 49.5 & 0 & $0.1795(1)$ & 0 & 0.51 & 15 & 4 & 46 & - & 4 & - \\
\hline & 49.3 & 0 & $0.1794(1)$ & 0 & 0.47 & 12 & 4 & 45 & - & 4 & - \\
\hline \multirow[t]{2}{*}{ M3 } & 6.2 & 0 & 0 & 0 & 1.00 & 37 & 6 & 82 & - & 1 & - \\
\hline & 5.6 & 0 & 0 & 0 & 0.82 & 26 & 6 & 65 & - & -3 & - \\
\hline \multirow[t]{2}{*}{ M4 } & 8.7 & 0 & $0.2712(2)$ & - & 1.90 & 61 & 20 & 125 & - & 49 & - \\
\hline & 7.2 & 0 & $0.2702(3)$ & - & 1.58 & 44 & 19 & 89 & - & 37 & - \\
\hline \multirow[t]{2}{*}{ M4' } & 2.3 & 0 & $0.2452(7)$ & - & 0.80 & & & & & & \\
\hline & 2.0 & 0 & $0.2435(9)$ & - & 0.99 & & & & & & \\
\hline \multirow[t]{2}{*}{ A } & 0.5 & 0 & - & 0 & 1.89 & 10 & 37 & 64 & - & 16 & - \\
\hline & 0.6 & 0 & - & 0 & 1.29 & 41 & 12 & 133 & - & 74 & - \\
\hline \multirow[t]{2}{*}{$\mathrm{A} m$} & 8.9 & $0.0660(4)$ & - & $0.1340(8)$ & 2.45 & 96 & 13 & 304 & - & 137 & - \\
\hline & 9.2 & $0.0671(5)$ & - & $0.1364(9)$ & 2.31 & 95 & 14 & 254 & - & 1258 & - \\
\hline \multirow[t]{2}{*}{$\mathrm{H}$} & 0.5 & $0.1684(9)$ & 0 & $0.7115(15)$ & 1.88 & & & & & & \\
\hline & 0.4 & $0.1973(9)$ & 0 & $0.7580(15)$ & 3.65 & & & & & & \\
\hline
\end{tabular}


TABLE 6. Selected interatomic distances $(\AA)$ and angles $\left({ }^{\circ}\right)$

\begin{tabular}{|c|c|c|c|c|c|c|c|}
\hline & & $P(1)$ & $P(2)$ & & & $\mathrm{P}(1)$ & $\mathrm{P}(2)$ \\
\hline \multicolumn{2}{|l|}{$\mathrm{T} 1-\mathrm{O} 1$} & $1.604(2)$ & $1.602(2)$ & M4 -O2 & $\times 2$ & $2.300(4)$ & $2.286(5)$ \\
\hline \multicolumn{2}{|l|}{-05} & $1.621(2)$ & $1.622(2)$ & -04 & $\times 2$ & $2.170(2)$ & $2.162(2)$ \\
\hline \multicolumn{2}{|l|}{-06} & $1.619(2)$ & $1.617(2)$ & -05 & $\times 2$ & $2.981(3)$ & $2.993(4)$ \\
\hline \multicolumn{2}{|l|}{-07} & $1.628(1)$ & $1.630(1)$ & -06 & $\times 2$ & $2.500(4)$ & $2.513(5)$ \\
\hline \multicolumn{2}{|l|}{$<\mathrm{T} 1-\mathrm{O}\rangle$} & 1.618 & 1.618 & $<\mathrm{M} 4-\mathrm{O}>$ & & 2.488 & 2.488 \\
\hline \multicolumn{2}{|l|}{ T2 -O2 } & $1.624(2)$ & $1.623(2)$ & M4'-O2 & $\times 2$ & $1.970(2)$ & $1.949(2)$ \\
\hline \multicolumn{2}{|l|}{-04} & $1.596(2)$ & $1.592(2)$ & -04 & $\times 2$ & $2.135(2)$ & $2.133(2)$ \\
\hline \multicolumn{2}{|l|}{-05} & $1.638(2)$ & $1.639(2)$ & -05 & $\times 2$ & $3.277(2)$ & $3.299(2)$ \\
\hline \multicolumn{2}{|l|}{-06} & $1.645(2)$ & $1.644(2)$ & -05 & $\times 2$ & $2.874(2)$ & $2.898(2)$ \\
\hline \multicolumn{2}{|l|}{$<\mathrm{T} 2-\mathrm{O}>$} & 1.626 & 1.624 & \multicolumn{2}{|c|}{$<{ }^{[6]} M 4^{\prime}-O>$} & 2.326 & 2.327 \\
\hline M1-O1 & $\times 2$ & $2.053(2)$ & $2.055(2)$ & $\mathrm{A} m-\mathrm{O} 5$ & $\times 2$ & $2.713(2)$ & $2.711(2)$ \\
\hline$-\mathrm{O} 2$ & $\times 2$ & $2.140(2)$ & $2.144(2)$ & -05 & $\times 2$ & $3.031(2)$ & $3.034(2)$ \\
\hline-03 & $\times 2$ & $2.032(2)$ & $2.030(2)$ & -06 & $\times 2$ & $2.671(2)$ & 2.663(2) \\
\hline \multicolumn{2}{|l|}{$<\mathrm{M} 1-\mathrm{O}>$} & 2.075 & 2.076 & \multicolumn{2}{|l|}{-07} & $2.445(3)$ & $2.447(2)$ \\
\hline M2-O1 & $\times 2$ & $2.081(2)$ & $2.080(2)$ & \multicolumn{2}{|l|}{-07} & $2.546(3)$ & $2.554(3)$ \\
\hline$-\mathrm{O} 2$ & $\times 2$ & $2.017(2)$ & $2.017(2)$ & \multicolumn{2}{|l|}{-07} & $3.014(3)$ & $2.998(3)$ \\
\hline-04 & $\times 2$ & $1.922(2)$ & $1.925(2)$ & \multicolumn{2}{|l|}{$<\mathrm{A} m-\mathrm{O}\rangle$} & 2.760 & 2.757 \\
\hline \multicolumn{2}{|l|}{$<\mathrm{M} 2-\mathrm{O}>$} & 2.007 & 2.007 & \multicolumn{2}{|l|}{$<\mathrm{A}-\mathrm{O}\rangle$} & 2.862 & 2.861 \\
\hline \multirow{4}{*}{$\begin{array}{c}\mathrm{M} 3-\mathrm{O} 1 \\
-\mathrm{O} 3 \\
<\mathrm{M} 3-\mathrm{O}>\end{array}$} & $\times 2$ & $2.105(2)$ & $2.104(2)$ & \multicolumn{2}{|l|}{$\mathrm{O} 3-\mathrm{H}$} & $0.500(3)$ & $0.775(2)$ \\
\hline & $\times 4$ & $2.125(3)$ & $2.133(3)$ & \multicolumn{2}{|l|}{$\mathrm{T} 1-\mathrm{T} 1$} & 3.070 & 3.073 \\
\hline & & 2.112 & 2.114 & \multicolumn{2}{|l|}{ O5-O6-O5 } & 172.16 & 172.16 \\
\hline & & & & \multicolumn{2}{|l|}{$\mathrm{A} m-\mathrm{O} 3$} & 2.978 & 2.960 \\
\hline
\end{tabular}

a lobe pointing toward the M1 site (Fig. 1); note that the position of $\mathrm{Na}(\mathrm{M} 4, y / b=0.27)$ is dominant in the map due to its higher atomic number (11 vs. 3 ).

Extensive immiscibility of the two groups of B cations has been often advocated, and is the reason for the distinction between the two main amphibole groups. It is often confirmed by the presence of exsolution lamellae of the less abundant phase, which are actually common in cummingtonite especially in rocks equilibrated at low $T$. On the other hand, ${ }^{\mathrm{B}} \mathrm{Mn}^{2+} \sim 0.8$ apfu has been reported by Oberti and Ghose (1993) in a sodic amphibole from a Mn-formation at Tirodi (Maharastra, India) that was shown to be free from exsolution lamellae; in that case, however, the adjacent A sites were less than half occupied, as it is normally the case for ${ }^{\mathrm{B}}(\mathrm{Mg}, \mathrm{Fe}, \mathrm{Mn}, \mathrm{Li})$-amphiboles. Even higher cummingtonite components (up to 1.1 apfu) were reported by Oberti et al. (1999) in synthetic fluoro-amphiboles of nominal eckermannitic compositions, which actu-

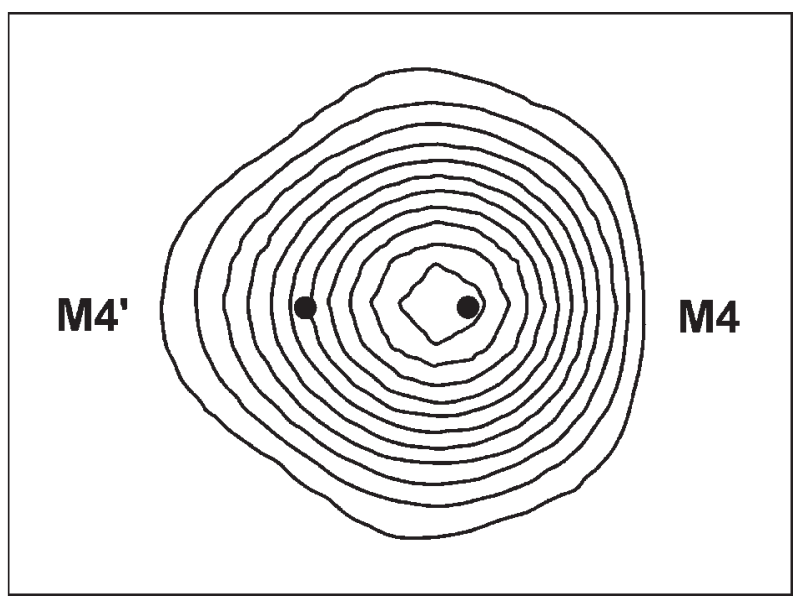

FIGURE 1. Electron-density distribution around the M4 site in sodic-ferripedrizite [projected onto (100)]. Contours at $1.0 \mathrm{e} / \AA^{3}$; dots give positions of M4' (Li) and M4 (Na). ally were found to be (A-filled) richterite on the basis of the charge-distribution pattern, but with $\mathrm{Mg}$ replacing $\mathrm{Ca}$ at the $\mathrm{B}$ sites. In their case, the temperature of the synthesis (slow cooling to $800{ }^{\circ} \mathrm{C}$ ) and the rapid quenching could be responsible for the lack of exsolution features. Few constraints can be put on the temperature of crystallization $\left(\leq 525{ }^{\circ} \mathrm{C}\right)$ of our amphiboles. In any case, the nearly equal amounts of $\mathrm{Na}$ and $\mathrm{Li}$ and the good crystal quality of the samples (the presence of exolution lamellae can be deduced by careful analysis of the diffraction data) confirm that miscibility between the two groups of B cations is far less difficult than previously thought, and occurs in both A-vacant and A-filled compositions.

Extensive substitution of $\mathrm{Mg}$ at the $\mathrm{B}$ cavity in synthetic richterite was shown to strongly affect the geometry of the B-, $\mathrm{C}$-, and T-sites, as well as cation ordering within the A cavity (Oberti et al. 1999). Sodic-ferripedrizite has the same chargedistribution pattern as leakeite, but with $\mathrm{Li}$ instead of $\mathrm{Na}$ at the B cavity.

\section{A-group sites}

${ }^{\mathrm{A}} \mathrm{Na}$ is preferentially ordered at the $\mathrm{A} m$ position, in line with the local association of ${ }^{\mathrm{A} m} \mathrm{Na}$ with ${ }^{\mathrm{B}} \mathrm{Na}$ in both amphiboles and fluoro-amphiboles (Hawthorne et al. 1996c) and with the observation that small cations in the B cavity further enhance this ordering via underbonding at the O5 anions (Oberti et al. 1999). The distance of Am from the center of the A cavity is much longer in sodic-ferripedrizite than in leakeite and fluoroferroleakeite $(0.84-0.85$ vs. $0.54-0.59 \AA)$. Thus, $\mathrm{Na}$ is forced to order at $\mathrm{A} m$ and it has to move further in the direction of the tetrahedral basal oxygen atoms [O5 and O6] so as to increase its incident bond-strength. This crystal-chemical role is confirmed by the very unusual shape of the electron density (Fig. 2) which, in the crystals of this work, assumes a butterfly-like conformation with lobes pointing in the direction of the basal $\mathrm{O}$ atoms. In sodic amphiboles (including leakeite), the shape of the electron density is that of a regular 8 , with the two lobes partly overlapping (cf. Fig. 6a in Hawthorne et al. 1996c). 


\section{T-group sites}

The short $<\mathrm{T} 1-\mathrm{O}>$ and $<\mathrm{T} 2-\mathrm{O}>$ distances indicate that only $\mathrm{Si}$ is present at the $\mathrm{T}$ sites. The tetrahedral double-chain is particularly stretched in sodic-ferripedrizite to link to the octahedral strip [enlarged by both the ${ }^{\mathrm{M} 2}\left(\mathrm{Fe}^{3+} \mathrm{Al}_{-1}\right)$ and ${ }^{\mathrm{M} 3}\left(\mathrm{LiMg}_{-1}\right)$ substitutions]. Accordingly, the T1-T1 distance and the O5-O6O5 angle are very large in sodic-ferripedrizite. The occurrence of $\mathrm{Al}$ at $\mathrm{T} 1$ is prevented in pedrizites by both of the following mechanisms: (1) the low charge at the M4 site and ordering of $\mathrm{Li}$ at M4' decreases the bond-strength to the $\mathrm{O} 5$ and $\mathrm{O} 6$ basal $\mathrm{O}$ (typical of clinoholmquistites); (2) the low charge at M3 due to the occurrence of ${ }^{\mathrm{C}} \mathrm{Li}$ decreases the bond-strength at the $\mathrm{O} 1$ apical $\mathrm{O}$ (typical of leakeites). The first mechanism is particularly effective, as some ${ }^{\mathrm{T} 1} \mathrm{Al}$ (up to $0.20 \mathrm{apfu}$ ) has been reported in leakeite and fluoro-ferroleakeite but is not present here. Compared to leakeite with $0.07{ }^{\mathrm{T} 1} \mathrm{Al}$ apfu, the T1-O6 and T1O5 distances are particularly short (1.619 vs. $1.624 \AA$ and 1.621 vs. $1.627 \AA$, respectively) whereas T1-O7 is fixed to minimize $\mathrm{Si}-\mathrm{Si}$ repulsion and to allow matching with the octahedral strip; the former features are due to the presence of ${ }^{\mathrm{B}} \mathrm{Li}$.

\section{C-Group SiTeS}

The refined site-scattering values indicate that significant ${ }^{\mathrm{C}} \mathrm{Li}$ is present in these crystals, and it is completely ordered at the $\mathrm{M} 3$ site; ${ }^{\mathrm{M} 3} \mathrm{Li}$ is higher in crystal $\mathrm{P}(1)$ than in crystal $\mathrm{P}(2)$, as indicated by the refined site-scattering. The refinement results (site scattering and mean bond-lengths) also indicate that: (1) $\mathrm{Fe}^{2+}$ is the other prevalent substituent at M3; (2) M1 is occupied by $\mathrm{Fe}^{2+}$ and $\mathrm{Mg}$; (3) all high-charge cations are ordered at M2.

Satisfaction of bond-strength requirements at the $\mathrm{O} 1$ and O3 anions mainly occurs within the octahedral strip by the entrance of additional high-charge cations and contraction of the M1-O3 bond. Further contribution comes from the contraction of the T1-O1 bond, which is promoted by (1) the absence of ${ }^{\mathrm{T} 1} \mathrm{Al}$; (2) high A-site occupancy; (3) ordering of ${ }^{\mathrm{A}} \mathrm{Na}$ at $\mathrm{Am}$. This crystal-chemical mechanism is the same as that proposed for leakeite by Hawthorne et al. $(1992,1994)$, and thus the presence of ${ }^{\mathrm{M} 3} \mathrm{Li}$ is constrained to the exchange vector ${ }^{\mathrm{M} 3} \mathrm{Li}^{{ }^{\mathrm{M}} 2} \mathrm{Fe}^{3+}$ ${ }^{\mathrm{M} 3} \mathrm{Mg}_{-1}{ }^{\mathrm{M} 2} \mathrm{Fe}_{-1}^{2+}$ applied to the charge-distribution pattern of eckermannite.

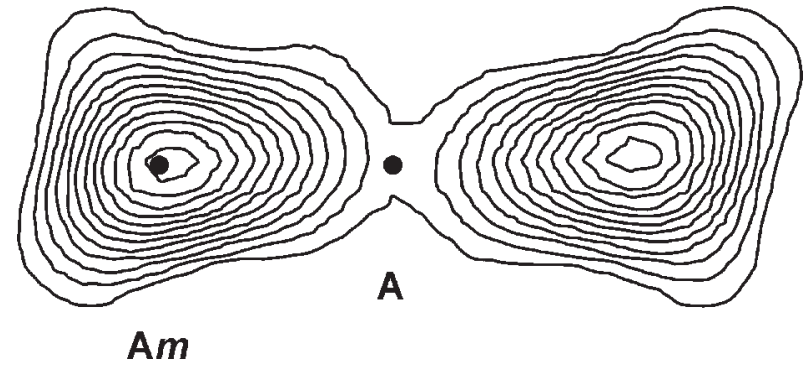

Figure 2. Electron-density distribution around the A site in sodicferripedrizite (best plane passing through $\mathrm{A}$ and $\mathrm{A} m$, dots giving their positions). Contours at $1.0 \mathrm{e} / \AA^{3}$.

\section{The $\mathbf{O 3}$ site}

Both the chemical analyses and the structure-refinement results indicate significant $\mathrm{F}$ at the $\mathrm{O} 3$ site. Dehydrogenation was reported for ${ }^{\mathrm{C}} \mathrm{Li}$-bearing amphiboles (Hawthorne et al. 1993), but matrix effects in the electron- and ion-microprobe analysis of F in silicates have been also reported (Solberg 1982; Ottolini et al. 2000). To clarify these points and to check for correlations between light and volatile elements, particular care was exercised during ion-microprobe analysis. Three pointanalyses were made on the smaller $\mathrm{P}(2)$ crystal and six on the larger $\mathrm{P}(1)$ crystal, and the signals of $\mathrm{H}, \mathrm{Li}$, and $\mathrm{F}$ (plus that of $\mathrm{Si}$ as the reference element) were collected at each point; an empirical correction for the effects of the Fe content on the ion-yield of F was also applied (CSCC, unpublished data). Whereas $\mathrm{P}(2)$ is substantially homogeneous, significant zoning was observed in $\mathrm{P}(1)$; the measured ranges were 1.60-2.14 wt $\%$ for $\mathrm{F}, 1.07-1.75 \mathrm{wt} \%$ for $\mathrm{H}_{2} \mathrm{O}$ and 3.29-4.40 wt \% for $\mathrm{Li}_{2} \mathrm{O}$. There is a strong negative correlation between the $\mathrm{F}$ and $\mathrm{H}_{2} \mathrm{O}$ in crystal $\mathrm{P}(1)(r=0.98)$, which confirms both the quality of the analyses and the absence of significant dehydrogenation. The negative correlation between $\mathrm{Li}_{2} \mathrm{O}$ and $\mathrm{H}_{2} \mathrm{O}$ and the positive correlation between $\mathrm{Li}_{2} \mathrm{O}$ and $\mathrm{F}(r=0.94)$ also validate the analysis of $\mathrm{Li}$, and confirm that its incorporation at M3 is locally associated with the presence of $\mathrm{F}$ at $\mathrm{O} 3$. The higher $\mathrm{F}$ contents obtained from ion-probe analysis are in a better agreement with the refinement results, in terms of both site scattering and changes in bond-lengths (cf. M1-O3 and M3-O3).

\section{RELATIONSHIPS WITH OTHER LI-BEARING AMPHIBOLES} Unit-cell parameters

Plots comparing unit-cell parameters in Li-bearing amphiboles as a function of the total $\mathrm{Li}$ contents are not informative. Better results are obtained when differentiating Li occurring at M3 from Li occurring at M4 in the ${ }^{\mathrm{B}} \mathrm{Na}$ - and ${ }^{\mathrm{B}} \mathrm{Li}$-amphiboles (Fig. 3). The situation is still rather complex, as heterovalent substitutions and homovalent substitutions [e.g., $\mathrm{Fe}^{2+} \mathrm{Mg}_{-1}$, $\left.\mathrm{Fe}^{3+} \mathrm{Al}_{-1}, \mathrm{~F}(\mathrm{OH})_{-1}\right]$ both affect the unit-cell edges. However, it is clear from Figure that sodic-ferripedrizite is intermediate between the two groups, and that the two groups may be discriminated on the basis of unit-cell parameters. The $b$ edge is less critical in this regard probably because it is most affected by the homovalent substitutions listed above; in particular $\mathrm{LiMg}_{-1}$ at M3 increases the $b$ value, but is somewhat masked by the concomitant $\mathrm{Fe}^{3+} \mathrm{Fe}_{-1}^{2+}$ at $\mathrm{M} 2$ (cf. the position of sodic ferri-clinoferroholmquistite). The $c$ edge is most sensitive to ${ }^{\mathrm{T} 1} \mathrm{Al}$; however, the shorter $c$ values observed in the presence of ${ }^{\mathrm{B}} \mathrm{Li}$ is in agreement with that observed in synthetic ${ }^{\mathrm{B}} \mathrm{Mg}$ richterites (Oberti et al. 1999). The $a$ edge increases in both groups as a function of $\mathrm{Li}$ at M3. The $\beta$ angle is strongly dependent on the nature of the B-group cations, and the deviations observed for sodic-ferripedrizite and for leakeite are due to their ${ }^{\mathrm{B}} \mathrm{Na}$ and ${ }^{\mathrm{B}} \mathrm{Ca}$ contents, respectively.

\section{Crystal-chemical mechanisms}

When compared to clinoholmquistite (Table 8) and to the other Mg-Fe-Mn-Li amphiboles end-members, sodicferripedrizite has complete A-site occupancy and low octahe- 

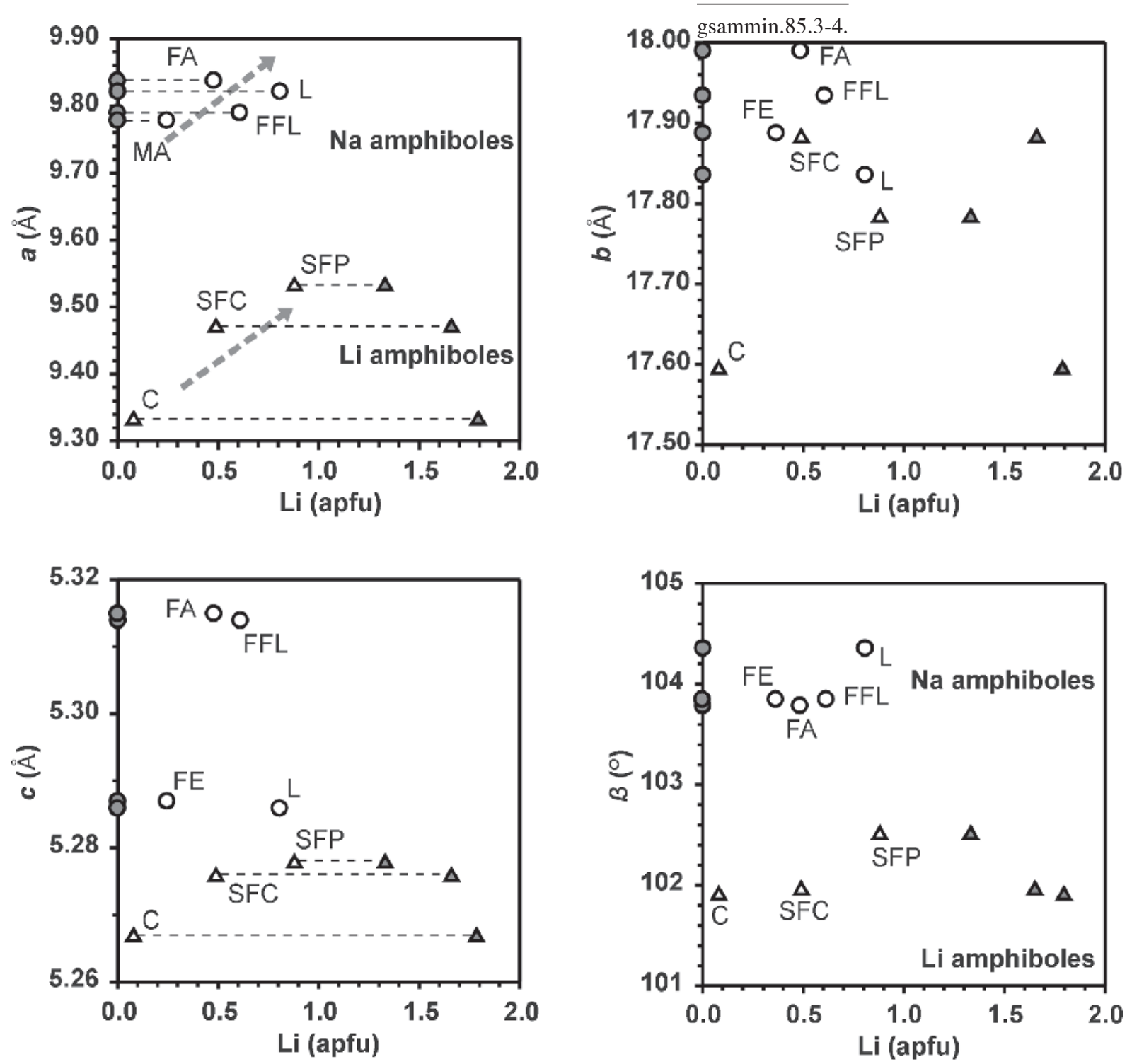

Figure 3. Variation in unit-cell parameters as a function of the ${ }^{\mathrm{M} 3} \mathrm{Li}$ (open symbols) and ${ }^{\mathrm{M} 4} \mathrm{Li}$ (filled symbols) contents in monoclinic ${ }^{\mathrm{B}} \mathrm{Li}$ amphiboles (triangles) and sodic ${ }^{C} \mathrm{Li}$-bearing amphiboles (circles). $\mathrm{C}=$ sodian fluorian clinoholmquistite (Litvin et al. 1975); FA = fluoroarfvedsonite (Hawthorne et al. 1996a); MA = magnesio-arfvedsonite (crystal A5 in Hawthorne et al. 1994); FFL = fluoro-ferroleakeite (crystal A5 in Hawthorne et al. 1993); $\mathrm{L}=$ leakeite (Hawthorne et al. 1992); $\mathrm{SFC}=$ sodic ferri-clinoferroholmquistite (Caballero et al. 1998); SFP = sodic-ferripedrizite (this work). Dotted lines join samples where the given cell parameter is directly related to Li content, Li at M3 for $a$ edge and Li at M4 for $c$ edge.

dral charge which derive from the presence of (nearly) $1 \mathrm{Li}$ apfu at the M3 site; moreover, it has significant ${ }^{\mathrm{B}} \mathrm{Na}(>0.50$ apfu). These features are specific to the crystal-chemical behavior of sodic amphiboles, the only amphibole subgroup in which ${ }^{\mathrm{C}} \mathrm{Li}$ had been observed so far (with the exception of sodic ferri-clinoferroholmquistite, which has been found in the same locality). On the other hand, ${ }^{\mathrm{B}} \mathrm{Li}$ had never been observed in CLi-bearing sodic amphiboles.

This new amphibole end-member has crystal-chemical features intermediate between the two main amphibole groups. The two sites within the M4 cavity illustrate the different requirements of the two groups of cations, which can no longer be con- sidered incompatible. The chemical variability in the amphibole crystals at the Pedriza Massif confirms the existence of extensive solid solution between ${ }^{\mathrm{B}} \mathrm{Na}$ and ${ }^{\mathrm{B}} \mathrm{Li}$-clinoamphiboles.

Cursory inspection of the chemical formulae (Table 8) suggests that the heterovalent exchange vector relating this new amphibole end-member to clinoholmquistite is ${ }^{\mathrm{A}} \mathrm{Na}{ }^{\mathrm{C}} \mathrm{Li}^{\mathrm{A}} \square_{-1}{ }^{\mathrm{C}} \mathrm{Mg}_{-1}$; however, this substitution does not satisfy local bond-strength requirements. The refined bond-lengths and site-scattering values show that two different crystal-chemical mechanisms are simultaneously active. The substitution involving octahedral $\mathrm{Li}$ is ${ }^{\mathrm{M} 3} \mathrm{Li}^{\mathrm{M} 2} \mathrm{Fe}^{3+}{ }^{\mathrm{M} 3} \mathrm{Mg}_{-1}^{2+}{ }^{\mathrm{M} 2} \mathrm{Fe}_{-1}^{2+}$, i.e., that relating leakeite and other ${ }^{\mathrm{C}} \mathrm{Li}$ sodic amphiboles to the charge-distribution pattern 
TABLE 8. End-member compositions for all monoclinic ${ }^{B} \mathrm{Li}$ amphiboles and for selected sodic amphiboles in which ${ }^{\mathrm{C}} \mathrm{Li}$ has been reported

\begin{tabular}{|c|c|c|c|c|c|}
\hline Name & A & $\mathrm{B}$ & $\mathrm{C}$ & $T$ & $\mathrm{X}$ \\
\hline Clinoholmquistite & $\square$ & $\mathrm{Li}_{2}$ & $\mathrm{Mg}_{3} \mathrm{Al}_{2}$ & $\mathrm{Si}_{8}$ & $(\mathrm{OH})_{2}$ \\
\hline Ferri-clinoferroholmquistite & $\square$ & $\mathrm{Li}_{2}$ & $\mathrm{Fe}^{2+}{ }_{3} \mathrm{Fe}^{3+}{ }_{2}$ & $\mathrm{Si}_{8}$ & $(\mathrm{OH})_{2}$ \\
\hline Sodic-ferripedrizite & $\mathrm{Na}$ & $\mathrm{LiNa}$ & $\mathrm{Mg}_{2} \mathrm{Fe}^{3+}{ }_{2} \mathrm{Li}$ & $\mathrm{Si}_{8}$ & $(\mathrm{OH})_{2}$ \\
\hline Leakeite & $\mathrm{Na}$ & $\mathrm{Na}_{2}$ & $\mathrm{Mg}_{2} \mathrm{Fe}^{3+}{ }_{2} \mathrm{Li}$ & $\mathrm{Si}_{8}$ & $(\mathrm{OH})_{2}$ \\
\hline Fluoro-ferroleakite & $\mathrm{Na}$ & $\mathrm{Na}_{2}$ & $\mathrm{Fe}^{2+}{ }_{2} \mathrm{Fe}^{3+}{ }_{2} \mathrm{Li}$ & $\mathrm{Si}_{8}$ & $\mathrm{~F}_{2}$ \\
\hline Fluoro-arfvedsonite & $\mathrm{Na}$ & $\mathrm{Na}_{2}$ & $\mathrm{Fe}^{2+}{ }_{4} \mathrm{Fe}^{3+}$ & $\mathrm{Si}_{8}$ & $\mathrm{~F}_{2}$ \\
\hline Magnesio-arfvedsonite & $\mathrm{Na}$ & $\mathrm{Na}_{2}$ & $\mathrm{Mg}_{4} \mathrm{Fe}^{3+}$ & $\mathrm{Si}_{8}$ & $(\mathrm{OH})_{2}$ \\
\hline
\end{tabular}

of eckermannite. A combination of two other substitutions $\left({ }^{\mathrm{A}} \mathrm{Na}\right.$ ${ }^{\mathrm{M} 2} \mathrm{Fe}^{2+\mathrm{A}} \square_{-1}{ }^{\mathrm{M} 2} \mathrm{Fe}^{3+}{ }_{-1}$ and the homovalent but non-isomorphous ${ }^{\mathrm{B}} \mathrm{Na}{ }^{\mathrm{B}} \mathrm{Li}_{-1}$ ) relates the two amphibole groups [these latter are exactly the two vectors relating crystal $\mathrm{P}(1)$ with crystal $\mathrm{P}(2)$ ].

Comparison with what is observed in leakeites suggests that other crystals further enriched in $\mathrm{Fe}^{2+}$ or slightly depleted in $\mathrm{Fe}^{3+}$ are likely to occur given the proper rock-composition; this implies the existence of a new amphibole series, which groups around the root-name pedrizite and has the general formula ${ }^{\mathrm{A}}(\mathrm{Na}, \mathrm{K}){ }^{\mathrm{B}}(\mathrm{Li}, \mathrm{Na}, \mathrm{Ca}){ }^{\mathrm{C}}\left[\mathrm{Li}\left(\mathrm{Mg}, \mathrm{Fe}^{2+}, \mathrm{Mn}\right)_{2}\left(\mathrm{Fe}^{3+}, \mathrm{Al}\right)_{2}\right] \mathrm{Si}_{8} \mathrm{O}_{22}$ $(\mathrm{OH}, \mathrm{F}, \mathrm{Cl})_{2}$.

\section{ACKNOWLEDGMENTS}

We thank Bernard E. Leake for useful comments during the definition of the name of this new amphibole end-member, and Frank C. Hawthorne and Peter C. Burns for constructive criticisms to the manuscript. Thanks are also due to the staff of the C.A.I. "Luis Bru" (U.C. Madrid) for assistance in electron-microprobe analysis and to Maribel Sevillano (Instituto Geología Económica, C.S.I.C.), who made wet analyses.

\section{REFERENCES CITED}

Armstrong, J.T. (1989) CITZAF V3.03, combined ZAF and $\varphi(\rho z)$ electron probe correction programs. California Institute of Technology, Pasadena, U.S.A.

Caballero, J.M. (1993) Las episienitas de la Sierra de Guadarrama: Un caso singular de alteración hidrotermal de edad post-hercínica, 313 p. Thesis, Universidad Complutense de Madrid.

Caballero, J.M. (1999) Modelización del proceso de episienitización (decuarcificaciónalbitización): Formulación cinética y transporte advectivo en medio continuo. Estudios Geológicos, 55, 9-26.

Caballero, J.M., Casquet, C., Tornos, F., and Pellicer, M.J. (1991) Caracterización petrográfica de las episienitas de la Sierra del Guadarrama, Sistema Central Español (S.C.E.). Boletín de la Sociedad Española de Mineralogía, 14, 273 284.

Caballero, J.M., Monge, A., La Iglesia, A., and Tornos, F. (1998) Ferriclinoferroholmquistite, $\mathrm{Li}_{2}\left(\mathrm{Fe}^{2}, \mathrm{Mg}\right)_{3} \mathrm{Fe}_{2}^{3+} \cdot \mathrm{Si}_{8} \mathrm{O}_{22}(\mathrm{OH})_{2}$, a new ${ }^{\mathrm{B}} \mathrm{Li}$ clinoamphibole from the Pedriza Massif, Sierra de Guadarrama, Spanish Central System. American Mineralogist, 83, 167-171.

Cathelineau, M. (1986) The hydrothermal alkali metasomatism effects on granitic rocks: Quartz dissolution and related subsolidus changes. Journal of Petrology, $27-4,945-965$.

González-Casado, J.M., Caballero, J.M., Casquet, C., Galindo, C., and Tornos, F. (1996) Palaeostress and geotectonic interpretation of the Alpine Cycle onset in the Sierra del Guadarrama (Eastern Iberian Central System), based on evidence from episyenites. Tectonophysics, 262, 213-229.

Hawthorne, F.C., Oberti, R.; Ungaretti, L.; and Grice, J.D. (1992) Leakeite, NaNa ${ }_{2}\left(\mathrm{Mg}_{2} \mathrm{Fe}_{2}^{3+} \mathrm{Li}\right) \mathrm{Si}_{8} \mathrm{O}_{22}(\mathrm{OH})_{2}$, a new alkali amphibole from the Kajlidongri manganese mine, Jhabua district, Madhya Pradesh, India. American Mineralogist, 77, $1112-1115$.

Hawthorne, F.C., Ungaretti, L., Oberti, R., Bottazzi, P., and Czamanske, G.K. (1993) $\mathrm{Li}$ an important component in alkali amphiboles. American Mineralogist, 78, 733-745.

Hawthorne, F.C., Ungaretti, L., Oberti, R., Cannillo, E., and Smelik, E.A. (1994) The mechanism of ${ }^{[6]} \mathrm{Li}$ incorporation in amphiboles. American Mineralogist, $79,443-451$.
Hawthorne, F.C., Ungaretti, L., and Oberti, R. (1995) Site populations in minerals: terminology and presentation of results of crystal-structure refinement. European Journal of Mineralogy, 33, 907-911.

Hawthorne, F.C., Oberti, R., Ottolini, L., and Foord, E.E. (1996a) Lithium-bearing fluor-arfvedsonite from Hurricane Mountain, New Hampshire: a crystal-chemical study. Canadian Mineralogist, 34, 1015-1019.

Hawthorne F.C., Oberti R., Ungaretti L., Ottolini L., Grice J.D., and Czamanske G.K. (1996b) Ferro-fluor-leakeite, $\mathrm{NaNa}_{2}\left(\mathrm{Fe}_{2}{ }^{2+} \mathrm{Fe}_{2}{ }^{3+} \mathrm{Li}\right) \mathrm{Si}_{8} \mathrm{O}_{22} \mathrm{~F}_{2}$, a new alkali amphibole from the Canada Pinabete Pluton, Questa, New Mexico, U.S.A. American Mineralogist, 81, 226-228.

Hawthorne, F.C., Oberti, R., and Sardone, N. (1996c) Sodium at the A site in clinoamphiboles: the effect of composition on patterns of order. Canadian Mineralogist, 34, 577-593.

Hawthorne F.C., Oberti R., Zanetti A., and Czamanske G.K. (1998) The role of Ti in hydrogen-deficient amphiboles: sodic-calcic and sodic amphiboles from Coyote Peak, California. Canadian Mineralogist, 36, 1253-1265.

Holland, T.J.B. and Redfern, S.A.T. (1997) Unit cell refinement from powder diffraction data: the use of regression diagnostics. Mineralogical Magazine, 61, 65-77.

Litvin, A.L., Ginzburg, I.V., Egorova, L.N., and Petrunina, A.A. (1975) On the crystal structure of clinoholmquistite. Konstitutsiya i Svoystva Mineralov, 9, 3-6.

Mandarino, J.A. (1981) The Gladstone-Dale relationships: IV. The compatibility concept and its application. Canadian Mineralogist, 19, 441-450.

Oberti, R. and Ghose, S. (1993) Crystal chemistry of a complex Mn-bearing alkali amphibole ("tirodite") on the verge of exsolution. European Journal of Mineralogy, 5, 1153-1160.

Oberti, R., Ungaretti, L., Cannillo, E., and Hawthorne, F.C. (1992) The behaviour of $\mathrm{Ti}$ in amphiboles. I. Four- and six-coordinated Ti in richterite. European Journal of Mineralogy, 7, 1049-1063.

Oberti, R., Hawthorne, F.C., Camara, F., and Raudsepp, M. (1999) Unusual M ${ }^{3+}$ cations in synthetic amphiboles with nominal fluoro-eckermannite composition: deviations from stoichiometry and structural effects of the cummingtonite component. American Mineralogist, 84, 102-111.

Ottolini, L., Bottazzi, P., and Vannucci, R. (1993) Quantification of Li, Be and B in silicates by secondary ion mass spectrometry using conventional energy filtering. Analytical Chemistry, 65, 1960-1968.

Ottolini, L., Bottazzi, P., and Zanetti, A. (1994) Quantitative analysis of hydrogen, fluorine and chlorine in silicates using energy filtering. In A. Benninghoven, Y Nihei, R. Shimizu and H.W. Werner, Eds., SIMS IX Proceedings, p. 191-194. Wiley, Chichester, U.K.

Ottolini, L., Bottazzi, P., Zanetti, A., and Vannucci, R. (1995) Determination of hydrogen in silicates by secondary ion mass spectrometry. Analyst, 120, 13091313.

Ottolini, L., Camara, F., and Bigi, S. (2000) An investigation of matrix effects in the analysis of fluorine in humite-group minerals by EMPA, SIMS and SREF. American Mineralogist, 85, 89-102

Solberg, T.N. (1982) Fluorine electron microprobe analysis: variations of X-ray peak shape. In K.F.J. Heinrich, Ed., Microbeam Analysis, p. 148-150. San Francisco Press Inc., California.

Villaseca, C. and Pérez-Soba, C. (1989) Fenómenos de alcalinización en granitoides hercínicos de la Sierra de Guadarrama (Sistema Central). Cuadernos Laboratorio Xeolóxico Laxe, 14, 201-212. 